Article

\title{
Response of Wetland Evapotranspiration to Land Use/Cover Change and Climate Change in Liaohe River Delta, China
}

\author{
Manqing Liu ${ }^{1,2}$ and Deyong $\mathrm{Hu}^{1,2, *}$ \\ 1 College of Resource Environment and Tourism, Capital Normal University, Beijing 100048, China; \\ 2180902126@cnu.edu.cn \\ 2 Beijing Key Laboratory of Resources Environment and Geographic Information System, \\ Beijing 100048, China \\ * Correspondence: deyonghu@cnu.edu.cn
}

Received: 8 April 2019; Accepted: 4 May 2019; Published: 7 May 2019

\begin{abstract}
This study aims to investigate the effects of land use/cover change (LUCC) and climate change on wetland evapotranspiration (ET), and to identify the importance of the main effect factors in the spatiotemporal dynamics of ET. In the wetland of Liaohe River Delta, China, the ET of eight growing seasons during 1985-2017 was estimated using the surface energy balance algorithm for land (SEBAL) model with Landsat and meteorological data. Results show that the average relative error of regional ET estimated by the SEBAL model is $9.01 \%$, and the correlation coefficient between measured and estimated values is 0.61 , which indicates that the estimated values are reliable. This study observed significant spatial and temporal variations in ET across the region of interest. The distribution of the average and relative change rate of daily ET in the study area showed bimodal characteristics, that is, the lowest trough occurred in 2005, whereas crests occurred in 1989 and 2014. Simultaneously, the daily ET varied with the land use/cover area. Regional daily ET displays highly heterogeneous spatial distribution, that is, the ET of different land uses/cover types in descending order is as follows: water body, wetland vegetation, non-wetland vegetation, and non-vegetation (except water area). Therefore, the spatial pattern of ET is relevant to the land use/cover types to some extent. In addition, the temporal variation of wetland ET is closely related to landscape transformation and meteorological factor change. A strong correlation was found between ET and the weighted values of meteorological factors, with a correlation coefficient of 0.69 . Meanwhile, the annual fluctuations of daily ET and the weighted values were relatively similar. Therefore, the findings highlight the importance of using cheap and readily available remote sensing data for estimating and mapping the variations in ET in coastal wetland.
\end{abstract}

Keywords: remote sensing; evapotranspiration; SEBAL; Liaohe River Delta wetland

\section{Introduction}

Water is one of the major factors controlling the formation and evolution of wetland [1-3]. Scientific allocation and utilization of limited water resources are the basis of maintaining the stability and sustainable development of wetland ecosystems. Evapotranspiration (ET) is an important component of hydrothermal balance and affects the water cycle of wetlands [4]. Therefore, ET is a key hydrological process, and its accurate estimation has some reference value for the optimal allocation and management of water resources.

In the context of global water scarcity and climate change, a deep understanding of the water consumption of different land uses/covers and the influences of meteorological factors is increasingly necessary to realize the rational utilization and optimal allocation of water resources. Land use/cover 
change (LUCC) is the result of the combined effect of human activity and natural environmental change, and plays a significant role in global environmental change and sustainable development. LUCC strongly affects ET, mainly by changing the nature of the underlying surface [4-8], for example surface reflectance, roughness, and vegetation cover. Meteorological factors influence ET primarily by changing the conditions of water vapor transport $[4,9,10]$. Therefore, research on the influences of LUCC and climate change on ET has theoretical and practical importance, which can provide scientific evidence for ecological environment protection, wetland restoration, and rational utilization of water resources. Substantial studies on this area have been conducted [11-13], especially on the combined effects of LUCC and climate change on ET [14-16], focusing on statistical analysis between LUCC and ET and correlation analysis between meteorological factors and ET. However, the combined effects of meteorological factors on ET are seldom reported.

Obtaining regional ET by conventional point-scale observation methods is difficult; however, it can be estimated by remote-sensing-based approaches [17]. Estimation methods of regional ET include empirical models and energy residual methods $[10,18,19]$. Empirical models apply remote-sensingbased parameters to traditional ET models. Energy residual methods are mainly divided into single-layer and multilayer models. The single-layer models handle land surface as one layer [20], which is suitable for high vegetation coverage and homogeneous underlying surfaces. Meanwhile, multilayer models consider the difference and interplay between soil and vegetation in water and heat transfer characteristics [21], which is applicable to low vegetation coverage and inhomogeneous underlying surface. In comparison with multilayer models, single-layer models have been used extensively because they can be operated simply; they require few readily available parameters, and their estimated results are reliable. Single-layer models include the surface energy balance algorithm for land (SEBAL) [22], the surface energy balance system [23], and mapping ET at a high resolution and internalized calibration [24]. Among these, SEBAL has extensively been used and validated in many countries, such as USA, Europe, China, South Asia, and Africa $[25,26]$.

The wetland area of the Liaohe River Delta, Northern China, has four rivers, namely the Liaohe, Daling, Xiaoling, and Daqing Rivers. This area has the largest phragmite reed field in the world, which is extensively managed [27]. Simultaneously, the wetlands in the Liaohe Delta provide habitats for a large number of species. Nevertheless, the trend of "warming and drying" is evident in the area due to the combined effects of climate change and human activity, thereby causing ecological water shortage. Therefore, the Liaohe River Delta wetland was selected as the study area in this work.

In this study, the response of wetland ET to LUCC and climate change in the Liaohe River Delta, China was investigated using the SEBAL model and statistical methods. In this manner, this study attempted to evaluate quantitatively the influences of LUCC and meteorological factors on wetland ET, especially the combined effect of multiple factors, to provide an important theoretical basis for the rational management and utilization of regional water resources.

\section{Study Area and Data}

\subsection{Study Area}

The study site is located in the Liaohe River Delta in Northeastern China $\left(40^{\circ} 30^{\prime}-41^{\circ} 30^{\prime} \mathrm{N}\right.$, $\left.121^{\circ} 10^{\prime}-122^{\circ} 30^{\prime} \mathrm{E}\right)$, which is composed of sediments from the Liaohe, Daling, Daqing, and Xiaoling Rivers (Figure 1). The study area covers approximately $6000 \mathrm{~km}^{2}$ and is characterized by a continental semi-humid monsoon climate, having wide seasonal variations with an average annual temperature, precipitation, and ET of $8.6^{\circ} \mathrm{C}, 631 \mathrm{~mm}$, and $1548 \mathrm{~mm}$, respectively [28]. The terrain is relatively flat, and the main vegetation types include natural wetland, artificial wetland, natural dryland, and constructed dryland vegetation. However, a tremendous conflict has existed between the development of social economy and the protection of the natural environment since 1985. This conflict has resulted in several inescapable problems, including the fragmentation of wetland landscape and change of habitat characteristics and ecological structure [29]. 


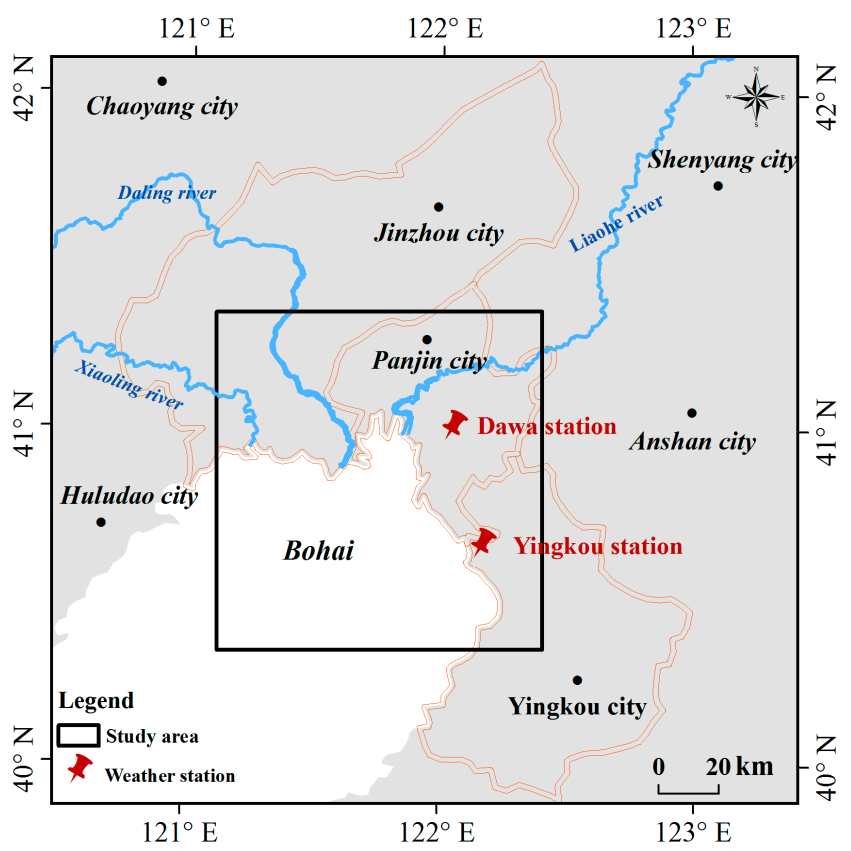

Figure 1. Location of the study area with weather stations.

\subsection{Data Acquisition and Pre-Processing}

Data used in the study included remote sensing, meteorological, and land use/cover data. Landsat series satellite data were downloaded from the National Aeronautics and Space Administration online web portal (http://ladsweb.nascom.nasa.gov/data/). The satellite data acquired and used for this study cover the growing season (i.e., July, August, and September) from 1985 to 2017 at a nearly five year period (Table 1). However, most of the remote sensing images were covered by clouds because the study area is close to Bohai Sea. Thus, obtaining same-day or same-month data is difficult. Remote sensing data were pre-processed, including radiometric calibration, atmospheric correction, image registration, and re-projection.

Table 1. Satellite data for surface energy balance algorithm for land.

\begin{tabular}{ccccc}
\hline Date & Overpass Time (UTC) & Satellite & Sensor & Temporal Resolution \\
\hline 13 July 1985 & $2: 04$ & & & 16 day \\
9 August 1989 & $2: 01$ & & & 16 day \\
11 September 1995 & $1: 37$ & Landsat-5 & TM & 16 day \\
8 September 2000 & $2: 12$ & & & 16 day \\
22 September 2005 & $2: 22$ & & & 16 day \\
15 July 2009 & $2: 23$ & Landsat-8 & OLI/TIRS & 16 day \\
30 August 2014 & $2: 43$ & & 16 day \\
7 September 2017 & $2: 34$ & & \\
\hline
\end{tabular}

Note: TM is Thematic Mapper, OLI is Operational Land Imager, and TIRS is Thermal Infrared Sensor.

The meteorological data used in this study were retrieved from fixed stations located in Dawa County and Yingkou City (Figure 1). The meteorological data included solar radiation, wind speed, air temperature, relative humidity, and evaporation, and were obtained from the National Climate Center, China Meteorological Administration (http://data.cma.cn). These datasets were available and were processed with quality control. Inverse distance weighted interpolation using the ArcGIS 10.2 extension tool was applied in the study area to obtain a good spatial representation of the meteorological inputs [30]. 
The land use/cover map of the study area (Figure 2) was extracted from Landsat data from 1985 to 2017 using a visual interpretation method. A total of 883 random samples were used for field checking. A confusion matrix was constructed to calculate the overall accuracy and kappa coefficient. The accuracy assessment results showed that the overall classification accuracy was $83.2 \%$ and that the overall kappa coefficient was 0.82 , which satisfied the study requirement. The region was further categorized into four zones (Table 2) on the basis of land use patterns to facilitate the following statistics.

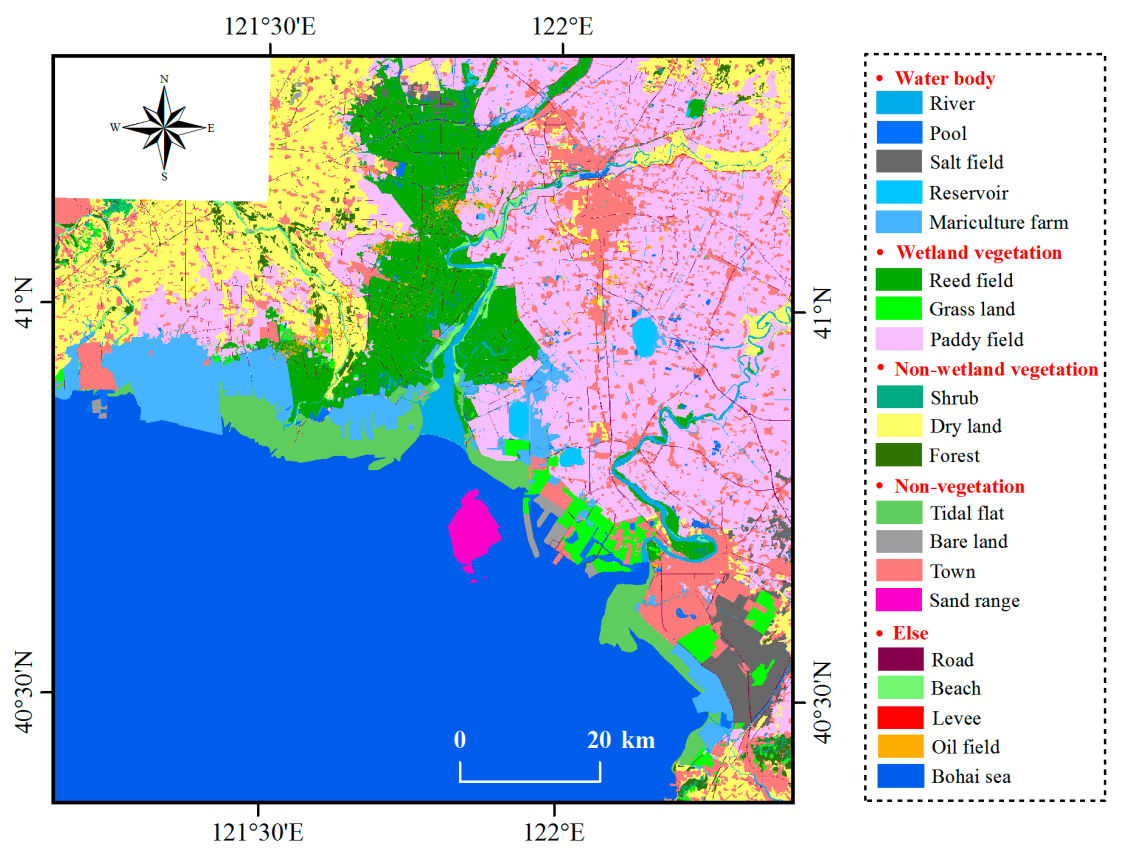

Figure 2. Land cover map of the study area. Note: Legend and the further grouping are located on the right of the map. To avoid statistical error, no analysis was made on the last group (road, beach, levee, oil field, and Bohai Sea), due to the small area.

\section{Methodology and Procedure}

\subsection{SEBAL Algorithm}

The SEBAL model was described in detail by Bastiaanssen et al. [31]. Its input requirements included remote sensing and meteorological data. The remote sensing parameters included surface temperature, emissivity, albedo, normalized difference vegetation index (NDVI), and fractional vegetation cover. The meteorological parameters included wind speed and air temperature. The SEBAL model estimated the instantaneous ET at the time of clear-sky satellite overpass on the basis of the energy balance equation, as follows:

$$
R_{n}-G-H-\lambda \mathrm{ET}=0
$$

where $R_{n}$ is the net surface radiation $\left(\mathrm{W} \cdot \mathrm{m}^{-2}\right), \mathrm{G}$ is the soil heat flux $\left(\mathrm{W} \cdot \mathrm{m}^{-2}\right), H$ is the sensible heat flux $\left(\mathrm{W} \cdot \mathrm{m}^{-2}\right), \lambda \mathrm{ET}$ is the latent heat flux $\left(\mathrm{W} \cdot \mathrm{m}^{-2}\right)$, and $\lambda$ is the latent heat of vaporization $\left(\mathrm{J} \cdot \mathrm{kg}^{-1}\right)$. The difference between short- and long-wave radiation fluxes at the land surface provides a $R_{n}$ value, as follows [22]:

$$
R_{n}=(1-\alpha) R_{S \downarrow}+\left(R_{L \downarrow}-R_{L \uparrow}\right)-(1-\varepsilon) R_{L \downarrow}
$$


where $\alpha$ is the surface albedo, $R_{s \downarrow}$ is the incoming short-wave radiation $\left(\mathrm{W} \cdot \mathrm{m}^{-2}\right), R_{L \downarrow}$ is the incoming long-wave radiation $\left(\mathrm{W} \cdot \mathrm{m}^{-2}\right), R_{L \uparrow}$ is the outgoing long-wave radiation $\left(\mathrm{W} \cdot \mathrm{m}^{-2}\right)$, and $\varepsilon$ is the surface emissivity. The components of Equation (2) were computed from Equations (3)-(9), as follows:

$$
\begin{gathered}
R_{S \downarrow}=\frac{G_{s c} \times \cos \theta}{d_{r}^{2}} \times \tau_{s w} \\
\theta=\arccos (\sin \varphi \sin \delta+\cos \varphi \cos \delta \cos t) \\
d_{r}=1+0.0167 \sin \left[\frac{2 \pi(J-93.5)}{365}\right] \\
\delta=0.409 \sin \left|\frac{2 \pi}{365} J-1.39\right| \\
t=\pi \frac{N-12}{12} \\
R_{L \uparrow}=\varepsilon \times S \times T_{s}^{4} \\
R_{L \downarrow}=1.08\left(-\ln \tau_{s w}\right)^{0.265} \times S \times T_{a}
\end{gathered}
$$

where $G_{s c}$ is the solar constant $\left(1367 \mathrm{~W} \cdot \mathrm{m}^{-2}\right), \theta$ is the solar zenith angle, $d_{r}$ is the inverse relative distance of the Earth-Sun, $\tau_{s w}$ is the atmospheric unidirectional transmittance, $\varphi$ is the station latitude, $\delta$ is the solar declination, $t$ is the sunset hour angle, $J$ is the date of the image acquisition in solar calendar, $N$ denotes the local time, $S$ is the Stefan-Boltzmann constant $\left(5.67 \mathrm{~W} \cdot \mathrm{m}^{-2} \cdot \mathrm{K}^{-4}\right), T_{a}$ denotes the air temperature $(\mathrm{K})$, and $T_{s}$ represents the surface temperature $(\mathrm{K})$. The parameter values of $\varepsilon, \alpha$, and $T_{s}$ were derived from the visible, near-infrared, and thermal infrared bands of Landsat data [32]. The soil heat flux $G$ was calculated using the empirical equation of Wang et al. [25], which can be expressed as follows:

$$
G=\frac{T_{s}-273.16}{\alpha} \times\left[0.0032 \times \frac{\alpha}{c 11}+0.0062 \times\left(\frac{\alpha}{c 11}\right)^{2}\right] \times\left(1-0.978 I^{4}\right) \times R_{n}
$$

where $I$ is the NVDI. The value of $c 11$ is related to the local time of satellite transit, as follows: (i) when the transit time is before 12:00, $c 11$ equals 0.9 ; (ii) when the transit time is between 12:00 and 14:00, $c 11$ equals 1.0; and (iii) when the transit time is between 14:00 and 16:00, $c 11$ equals 1.1. The sensible heat flux $H$ was derived using Equation (11) [22], as follows:

$$
H=\frac{\rho_{a i r} \mathrm{C}_{\mathrm{p}} d T}{\gamma_{a h}}
$$

where $\rho_{\text {air }}$ is the atmospheric air density $\left(\mathrm{kg} \cdot \mathrm{m}^{-3}\right), C_{p}$ is the specific heat of air at constant pressure $\left(1004 \mathrm{~J} \cdot \mathrm{kg}^{-1} \cdot \mathrm{K}^{-1}\right), \gamma_{a h}$ is the aerodynamic resistance to heat transport $\left(\mathrm{s} \cdot \mathrm{m}^{-1}\right)$, and $d T$ is the near-surface temperature difference $(\mathrm{K})$.

The instantaneous fluxes at the moment of satellite overpass on a pixel-by-pixel basis were calculated using SEBAL through a series of computations that generated the following: net surface radiation $\left(R_{n}\right)$, soil heat flux $(G)$, and sensible heat flux to the air $(H)$. The soil and sensible heat fluxes were subtracted from the net radiation at the surface, and the "residual energy" would be the latent heat flux ( $\lambda \mathrm{ET})$ used for ET, as follows:

$$
\lambda \mathrm{ET}=R_{n}-G-H
$$

Latent heat of vaporization $\lambda$ was derived as follows [33]:

$$
\lambda=2.501-0.002361 \times\left(T_{s}-273.15\right)
$$


Evaporative fraction $(\mathrm{EF})$, which is the ratio of the actual evaporation to total available energy, is conservative in a diurnal cycle, and can be assumed to be representative of daily energy partitioning during cloud-free conditions [34]. Therefore, instantaneous EF at the satellite overpass time was used to compute daily values of $E F_{d}$, and was then scaled up to daily $E F_{d}$ by estimating the average $24 \mathrm{~h}$ net radiation [35]. For timescales of one day or longer, the averaged $24 \mathrm{~h}$ soil heat flux $\left(G_{d}\right)$ was constantly ignored [36].

$$
\begin{gathered}
\mathrm{EF}=\frac{\lambda \mathrm{ET}}{R_{n}-G}=E F_{d}=\frac{\lambda E T_{d}}{R_{n d}-G_{d}}=\frac{\lambda E T_{d}}{R_{n d}} \\
E T_{d}=\frac{E F_{d} \times R_{n d}}{\lambda}
\end{gathered}
$$

In the absence of eddy covariance data, alternatives were limited for selecting small-scale pan evaporation data for the two meteorological stations located in Dawa County and Yingkou City as testing data. In addition, the remote sensing estimates of SEBAL were validated against ground-based observed meteorological data. The SEBAL results, averaged over $3 \mathrm{~km} \times 3 \mathrm{~km}$ centered at the water body sample closest to the weather station, were typically used for comparison with small-scale pan evaporation data. However, the evaporation condition of the pan was different from that of the natural water body. Therefore, different conversion coefficients were set to correct the pan evaporation data. Small-scale pan evaporation data were converted into natural water body, as follows [37,38]:

$$
\begin{gathered}
E_{0}=E_{1} \times 0.98 \\
E_{1}=E_{2} \times k
\end{gathered}
$$

where $E_{0}$ is the ET of natural water body, $E_{1}$ is the large-scale pan evaporation, $E_{2}$ is the small-scale pan evaporation, and $k$ is the conversion coefficient. Values of $k$ were not observed in January, February,

\begin{tabular}{|c|c|c|c|c|c|c|c|c|c|c|c|c|c|}
\hline \multirow[b]{2}{*}{$\mathbf{k}$} & \multicolumn{12}{|c|}{ Monthly Average } & \multirow{2}{*}{$\begin{array}{c}\text { Annually Average } \\
0.56\end{array}$} \\
\hline & 1 & $\begin{array}{l}2 \\
1\end{array}$ & $\begin{array}{l}3 \\
1\end{array}$ & $\begin{array}{c}4 \\
0.51\end{array}$ & $\begin{array}{c}5 \\
0.55\end{array}$ & $\begin{array}{c}6 \\
0.53\end{array}$ & $\begin{array}{c}7 \\
0.54\end{array}$ & $\begin{array}{c}8 \\
0.56\end{array}$ & $\begin{array}{c}9 \\
0.57\end{array}$ & $\begin{array}{c}10 \\
0.59\end{array}$ & $\begin{array}{c}11 \\
/\end{array}$ & $\begin{array}{c}12 \\
/\end{array}$ & \\
\hline
\end{tabular}
March, November, and December due to winter. The values of $k$ in the growing season are shown in Table 2.

Table 2. Average conversion coefficient of $E_{2}$ to $E_{1}$ in Liaoning Province.

\subsection{Method for Analyzing the Influencing Factors of ET}

The "weighted comprehensive analysis method for meteorological factors" was proposed to explore the influencing factors of ET. This method mainly used the proportion of the Pearson correlation between ET and four meteorological factors (i.e., radiation, average temperature, wind speed, and relative humidity) as weights and the normalized values of four meteorological factors as factors. To analyze the influence of the four meteorological factors on ET, their normalized values were synthesized by weights, and their normalized weighted values were obtained.

To assess the linear relationship between ET and meteorological factors, the Pearson correlation was provided, as follows:

$$
R_{x, y}=\frac{\sum_{i=1}^{n}\left[\left(x_{i}-\bar{x}\right)\left(y_{i}-\bar{y}\right)\right]}{\sqrt{\sum_{i=1}^{n}\left(x_{i}-\bar{x}\right)^{2} \sum_{i=1}^{n}\left(y_{i}-\bar{y}\right)^{2}}}
$$

where $x$ and $y$ are two generic sequential values of the variable, $n$ is the length of the data set, and $\bar{x}$ and $\bar{y}$ are the average values of the two variables. $R_{x, y}$ can be positive (indicating an increasing trend) or negative (indicating a decreasing trend). The absolute value of $R_{x, y}$ represents the degree of correlation. 


\section{Results}

\subsection{Validation of SEBAL Results}

The estimated ET was validated using meteorological data. Small-scale pan evaporation data collected from two meteorological stations located in Dawa County and Yingkou City were converted into natural water body using Equations (16) and (17). In view of the scale problem, samples were collected from the water body nearest the meteorological station using fixed-area plot sampling. Figure 3 shows the correlations between the measured and estimated values from 1985 to 2017. An error analysis was conducted, and its result is shown in Table 3.

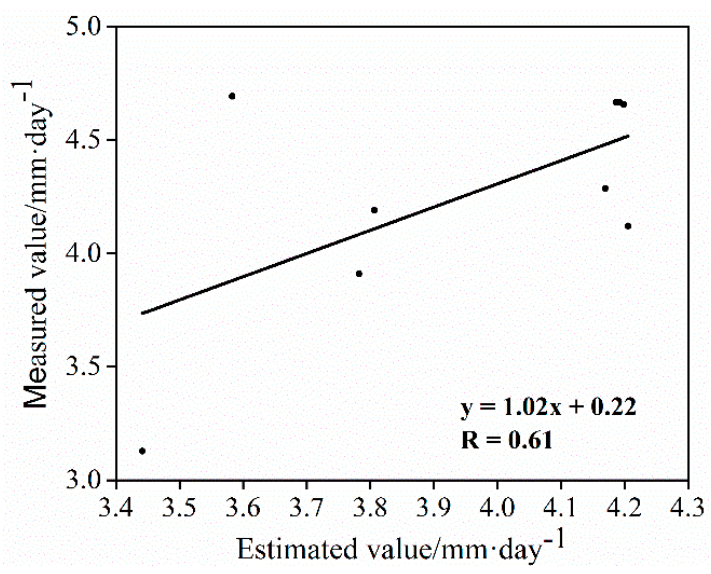

Figure 3. The statistical regression relation between the measured values and the estimated values. The solid line is the regression line fitted to the data comparison points.

Table 3. The precision assessment between the measured value and the estimated values of ET.

\begin{tabular}{|c|c|c|c|c|}
\hline Weather Station & Time & Estimated Value/mm & Measured Value/mm & Relative Error/\% \\
\hline \multirow{6}{*}{ Dawa station } & 13 July 1985 & 4.20 & 4.66 & 9.85 \\
\hline & 9 August 19 & 4.20 & 4.66 & 10.13 \\
\hline & 11 September 1995 & 3.81 & 4.19 & 9.14 \\
\hline & 8 September 2000 & 3.78 & 3.91 & 3.28 \\
\hline & 22 September 2005 & 3.44 & 3.13 & 10.02 \\
\hline & 30 August 2014 & 4.21 & 4.12 & 2.04 \\
\hline \multirow{2}{*}{ Yingkou station } & 8 September 1989 & 4.19 & 4.66 & 10.23 \\
\hline & 8 September 2000 & 3.58 & 4.69 & 23.64 \\
\hline Mean & - & - & - & 9.01 \\
\hline
\end{tabular}

The results showed a reasonable correlation between the measured and estimated values of ET $(R=0.61$, sig $<0.05$; Figure 3$)$ with a mean relative error of $9.01 \%$, which indicates that the estimated values were reliable.

\subsection{Spatial and Temporal Variations of ET}

Figure 4 shows the temporal variation trend of the actual ET and the relative change rate in the study area from 1985 to 2017. The curve of the relative change rate showed bimodal characteristics, with values ranging from $-17.21 \%$ to $8.31 \%$. Three inflection points were observed in 1989,2005 , and 2014. ET tended to increase at the beginning and then declined in 1989. The valley point of the curve occurred in 2005 and was selected as the "breaking point." The study period from 1985 to 2017 was divided into two parts, as follows: a 20 year period from 1985-2004, showing a significantly decreasing trend, and a 13 year period from 2005-2017, showing an increasing trend. Meanwhile, the maximum ET value $\left(3.70 \mathrm{~mm} \cdot \mathrm{day}^{-1}\right)$ was detected in 1989 , and the minimum ET value $\left(3.09 \mathrm{~mm} \cdot \mathrm{day}^{-1}\right) \mathrm{was}^{-1}$ detected in 2005. The mean ET in 1985-2017 was $3.40 \mathrm{~mm} \cdot \mathrm{day}^{-1}$ (the red dashed line in Figure 4), 
and the ET values in 2000, 2005, 2009, and 2017 were below average, with the largest gap (0.50 mm) occurring in 2005. A slightly decreasing trend of ET from 1985 to 2017 was also observed.

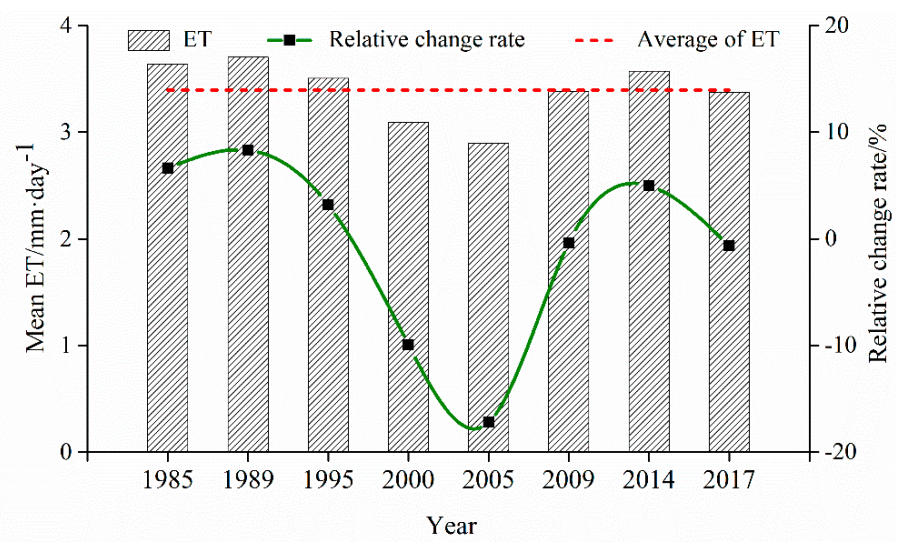

Figure 4. Interannual variation of ET over the Liaohe River wetland from 1985 to 2017.

The results in Figure 5 demonstrate the spatial variations of ET in the study area during the growing season from 1985 to 2017, with a gap of nearly five years. The results precisely demonstrated that ET varied significantly in space and over time. The results also confirmed that the water body had the highest ET estimates for the entire period, compared with other areas. By contrast, the area of land-water junction had the lowest ET during the entire period. In addition, higher values of ET were observed in the eastern, southern, and middle sections of the study area, whereas the western section showed a lower ET. This spatial pattern was due to the ET, which was closely related to land uses/cover types in the region to some extent (Figure 2). The reasons might be attributed to the following: (i) higher ET estimates experienced in the southern section of the region were, to some extent, linked to the water surface evaporation; (ii) the results, showing the higher values in the eastern and middle sections of the region, might be due to the large area of paddy and reed fields, and might result from the combined effects of water surface evaporation and vegetation transpiration; (iii) the land cover map showed that tidal flat, bare land, and sand range were located in the area of the water-land junction, which might result in lower ET because of low vegetation coverage, regardless of the effect of Bohai Sea. The heterogeneous spatial distribution of ET may be an indication that different land cover types exhibited different ET signatures.
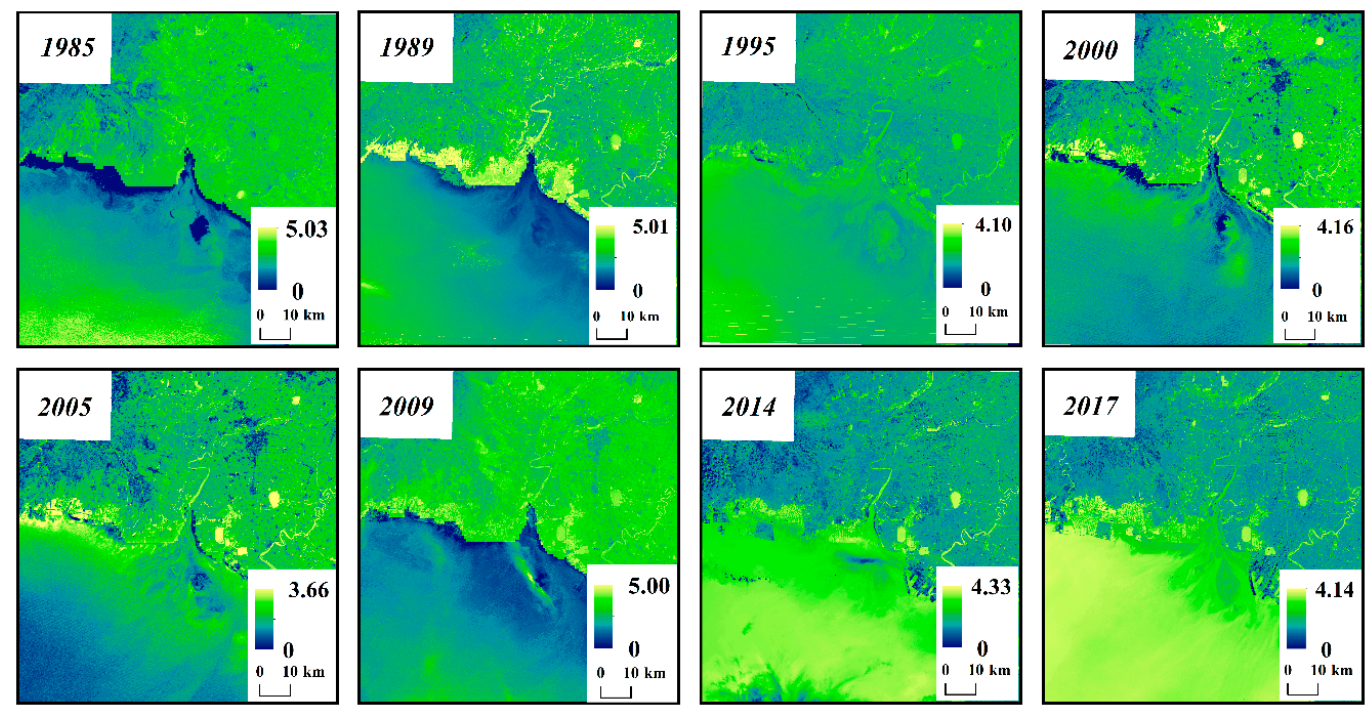

Figure 5. ET maps derived using the surface energy balance algorithm for land (SEBAL) model from 1985 to 2017. 


\subsection{Dominant Factors of ET}

\subsubsection{Effect of Land Cover on ET}

To derive ET estimates per land cover types, the zonal statistics function embedded in ArcGIS 10.2 was used to extract the ET estimates corresponding to the respective land types. Land-cover-based estimates from remote sensing provided a detailed understanding of ET variation across the study area. In 2000, the land cover types had different ET signatures, as shown in Figure 6. In summary, the water body and its surrounding environment had higher ET estimates than other land cover types. In addition, the ET estimates of the vegetation area were higher than those of the non-vegetation area. The different land uses/cover types, with ET in descending order, were as follows: water body, wetland vegetation, non-wetland vegetation, and non-vegetation (except water area). Related research has highlighted that water evaporation is the main component of the wetland ET process. Paddy and reed fields were the two largest areas of vegetation in the study area.

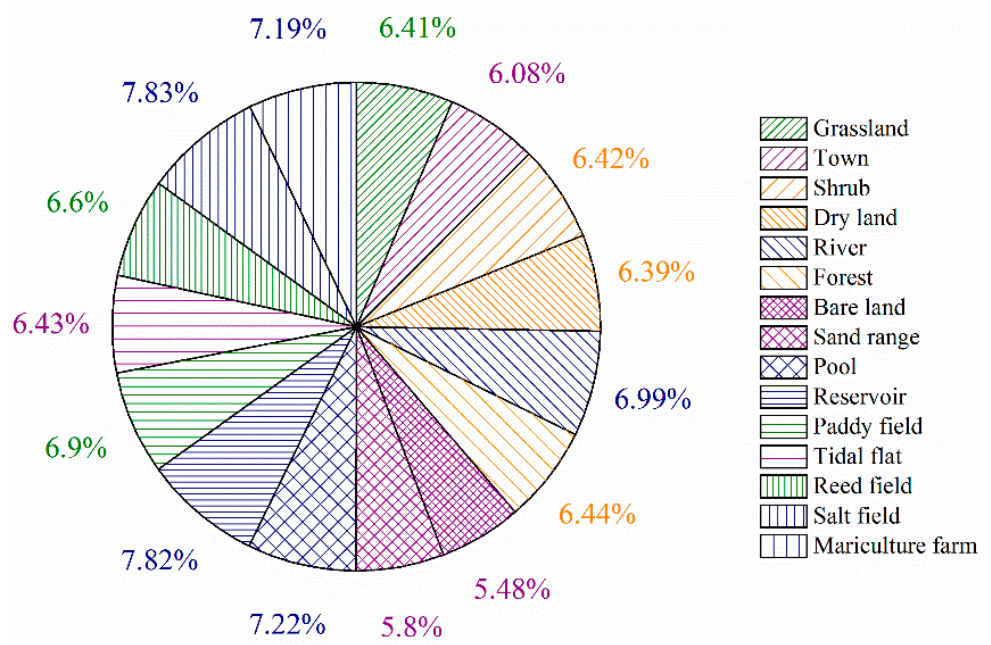

Figure 6. ET estimates across different land cover types, derived using zonal statistics in ArcGIS. Note: Different colors represent different land cover zones: blue is water body; green is wetland vegetation; orange is non-wetland vegetation; purple is non-vegetation.

Figure 7 shows the statistics of four various dominant land cover zones extracted from the mean ET map, based on an overlay of land use/cover map. From the figure, the temporal change of ET for four land cover zones included water body, wetland vegetation, non-wetland vegetation, and non-vegetation. The inflection points of various land cover zones in 1989, 2005, and 2014 were consistent with the interannual variation and trend of ET, as shown in Figure 5. The result also confirmed that water body had the highest ET estimates during the entire period, whereas non-vegetation had the lowest ET estimates in most years. Although lower water and vegetation coverage was shown in non-vegetation areas than in non-wetland vegetation and wetland vegetation areas, the difference was insignificant. For instance, the non-vegetation, non-wetland vegetation, and wetland vegetation estimates in 1995 and 2014 were not significantly different from those in 2017. The reason for this finding might be due to parts of the non-vegetation area, including tidal flat and sand range, being close to the Bohai Bay, which was greatly affected by the tides and caused the water to inevitably affect ET. In sum, the results confirmed that the ET of different land uses/cover types decreased in the following order: water body, wetland vegetation, non-wetland vegetation, and non-vegetation (except water area). 


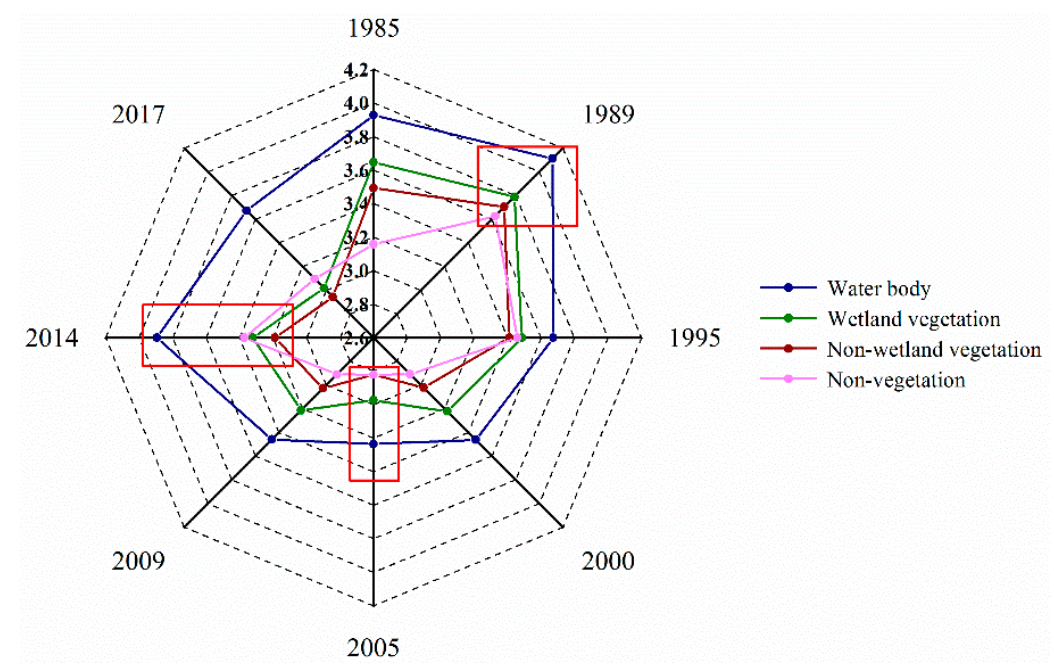

Figure 7. ET estimates across four land cover zones, derived using zonal statistics in ArcGIS from 1985 to 2017. Note: Red framed points represent inflection points of the time series during the study period.

Nevertheless, the influence of land use change on increasing and decreasing ET is well-known, and, in some cases, such an influence is considerably higher than those of climate variations. Therefore, further analysis of the area variation over different landscapes, and changes in total daily ET due to the area variation (Figure 8) was conducted to further understand the influence of land cover on ET. Figure 8 shows that the positive area change degrees of water body, non-wetland vegetation, and non-vegetation during this period decreased in the order of non-wetland vegetation, non-vegetation, and water body, with increments of $103.89,25.36$, and $12.75 \mathrm{~km}^{2}$, respectively. Wetland vegetation area had the largest decrement $\left(167.53 \mathrm{~km}^{2}\right)$ compared with the other three land cove zones. Although the four land cover zones showed some variations in the average ET estimates of per unit area over the years, the differences were insignificant. However, the considerable influence on total daily ET might be attributed to the larger area change. Eliminating the influence of the per unit area average ET of different landscape was necessary. The curve in Figure 9 shows that the total daily ET of the water body, non-wetland vegetation, and non-vegetation increased, with increments of $4.34 \times 10^{4}, 31.25 \times$ $10^{4}$, and $7.52 \times 10^{4} \mathrm{~m}^{3}$, respectively. However, wetland vegetation had the largest decrement $(5.45$ $\times 10^{4} \mathrm{~m}^{3}$ ), compared with the other three land cover zones. The variation characteristics of the total daily ET showed an agreement with the area change characteristics across the different land cover zones. These findings indicate that wetland vegetation transformation was the main land cover change characteristic, and that the total daily ET varied with the land cover area.

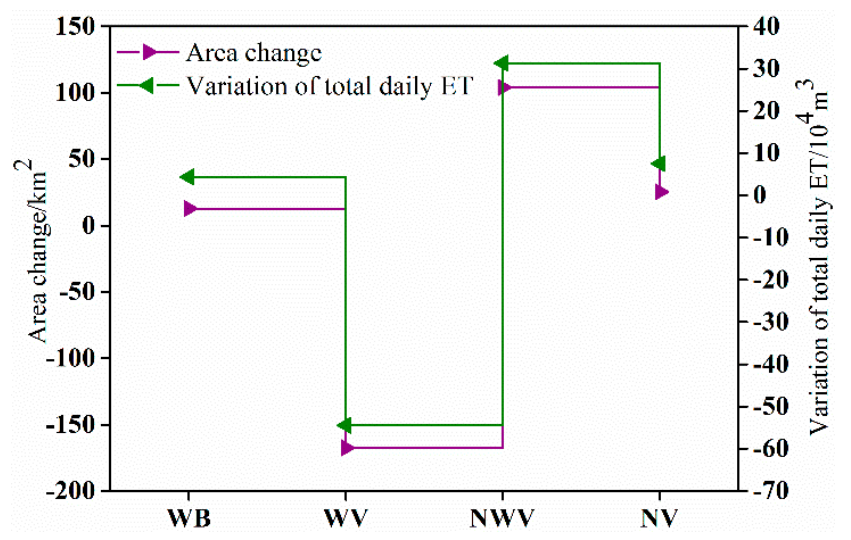

Figure 8. Area change and variation of total daily ET across the four land cover zones. Note: WB: water body; WV: wetland vegetation; NWV: non-wetland vegetation; NV: non-vegetation. 

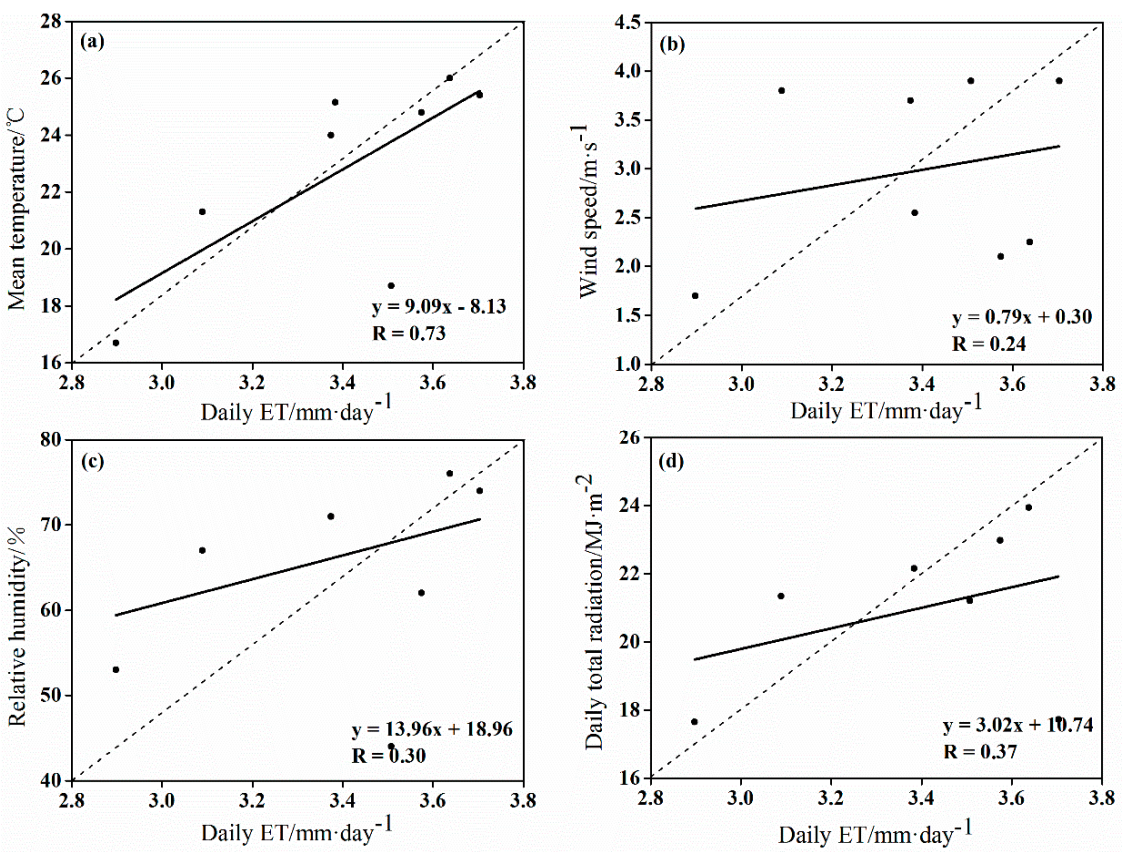

Figure 9. Correlation coefficients between ET and (a) mean temperature, (b) wind speed, (c) relative humidity, (d) daily total radiation.

\subsubsection{Effects of Meteorological Factors on ET}

Figure 10 shows the correlations between ET and meteorological factors. These results showed that ET was positively correlated to solar radiation, air temperature, wind speed, and relative humidity, with correlation coefficients of $0.37,0.73,0.24$, and 0.30 , respectively. The findings were consistent with the fact that increased temperature, wind speed, solar radiation, and relative humidity would lead to an increase in ET. In this study, the high values of correlation coefficient between air temperature and daily ET in the growing season indicated that the ET at the study site was influenced by air temperature.

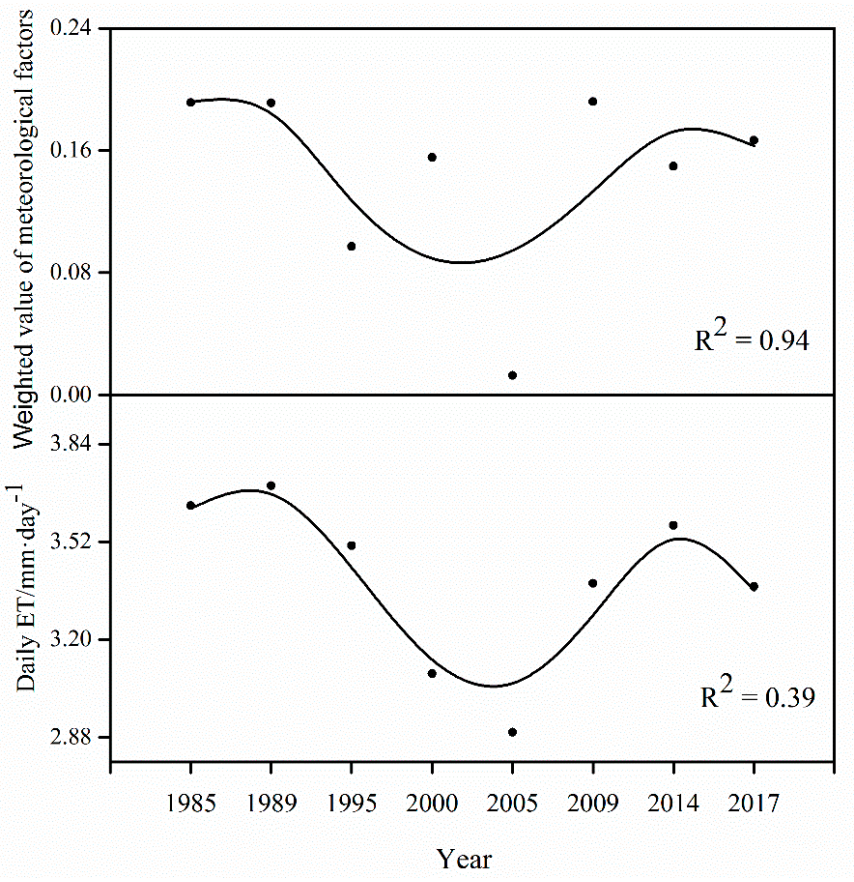

Figure 10. Relationship between weighted values of meteorological factors and daily ET of Liaohe River wetland. 
ET varied with temperature, wind speed, relative humidity, and solar radiation. ET was affected by multiple meteorological factors, and these factors might have mutual influences. Thus, the weighted comprehensive analysis method for meteorological factors might be appropriate to identify the relationship between ET and all meteorological variables. The temporal variation trend of ET and the weighted values of meteorological factors is shown in Figure 10. The curves in the graph were polynomial fitting curves of degree 5 . A strong correlation was found between ET and the weighted values of meteorological factors, with a correlation coefficient of 0.69 , and a similar trend was observed between 1985 and 2017. Therefore, the weighted values of the four climate factors may explain the change in ET. Figures 5 and 8 show that the ET in 2005 had the minimum value in the curve. The change in ET in 2005 was caused by the lowest values of average air temperature, wind speed, and solar radiation, with values of $16.7^{\circ} \mathrm{C}, 1.7 \mathrm{~m} / \mathrm{s}$, and $17.65 \mathrm{MJ} \cdot \mathrm{m}^{-1}$, respectively.

\section{Discussion}

In recent decades, the relationships between ET and climatic factors have been widely studied $[39,40]$. The main climatic factors affecting ET include precipitation, solar radiation, air temperature, wind speed, and relative humidity, etc. [41]. Precipitation determines the water supply conditions, and further controls ET to a certain extent [42]. However, the study area in this paper is a coastal wetland with good water supply conditions, so the energy conditions and atmospheric demand factors controlled by air temperature, wind speed, solar radiation, and relative humidity play a decisive role [8]. Air temperature, wind speed, and solar radiation were positively correlated with ET, which is consistent with the results obtained by others $[8,43,44]$. Solar radiation determines the energy supply; air temperature affects the movement of water molecules on the underlying surface; wind speed affects water vapor transport during the evaporation process [8]. Previous studies have supported the finding in this paper that ET decreases with air temperature, wind speed, and solar radiation [45-47]. Therefore, the result might be attributed to the following: (i) the warming effect was weak on soil, vegetation, and air due to the low solar radiation; (ii) the low temperature weakened the water movement of the underlying surface; and (iii) the weak near-ground wind speed was linked with a weak capacity of moisture diffusion and heat transfer, accompanied by near-surface air flow. The combined influences of these factors might eventually result in a decrease in ET, including less plant transpiration and surface evaporation.

In addition to climate factors, ET is also affected by land use/cover and LUCC [5,48]. Moreover, LUCC may have a greater impact on the hydrological cycle than climate change [49]. LUCC is land transformation [50], which changes the underlying surface characteristics, such as soil moisture, vegetation index, leaf area index, vegetation coverage, surface roughness, surface albedo, surface temperature, etc., and further changes the water and heat balance at the surface. The underlying surface plays a crucial role in ET and directly determines the spatial distribution pattern of ET [51-53]. In this study, the ET of different land uses/cover types decreased in the following order: water body, wetland vegetation, non-wetland vegetation, and non-vegetation (except water area). This is mainly because the ET estimates were, to some extent, linked to the presence of the water body and vegetation coverage [54]: the ET of water bodies and their surrounding wetlands is higher, and that of vegetation areas is larger than that of non-vegetation areas [55].

\section{Conclusions}

The spatial and temporal changes of ET and its influencing factors were explored based on the SEBAL model over the Liaohe River wetland during the growing seasons in 1985, 1989, 1995, 2000, 2005, 2009, 2014, and 2017. The main conclusions of this study are as follows:

1. The results calculated by SEBAL were comparable with the values derived from pan observations, which indicated that the averaged relative error was $9.01 \%$. The correlation analysis indicated that the estimated versus measured ET results were consistent, with a correlation coefficient of 
0.61. Generally, the SEBAL model could be effectively used for estimating regional ET over the Liaohe River wetland.

2. From 1985 to 2017, the average value and relative change rate in ET showed bimodal characteristics in the study area, with the inflection points in 1989, 2005, and 2014; the average ET value was approximately $3.40 \mathrm{~mm} \cdot \mathrm{day}^{-1}$ for the entire area. A slightly decreasing trend of ET was also observed across the region. Local-scaled daily ET displayed highly heterogeneous spatial distribution, which was coherent with the land cover map to some extent.

3. During the study period, the underlying surface and climate conditions were the dominant factors contributing to ET. The different land uses/cover types with ET were, in decreasing order: water body, wetland vegetation, non-wetland vegetation, and non-vegetation (except water body). Meanwhile, the variation of wetland ET was closely related to landscape transformation and meteorological factor change. This study also developed a new method of weighted comprehensive analysis for meteorological factors (e.g., solar radiation, air temperature, wind speed, and relative humidity), which could explain the temporal variation trend of ET to a certain extent.

Overall, the SEBAL model proved to be a useful tool for ET estimation. The results provided an in-depth understanding of the effects of LUCC and climate change on ET in the wetland area. Although reliable estimations were obtained, the validation of SEBAL results using pan observations may be somewhat uncertain. Moreover, there is a need to explore the application of the meteorological factor weighted comprehensive analysis method for explaining temporal change in other regions.

Author Contributions: M.L. and D.H. contributed to experimental design and article conception. M.L. performed experiment and wrote the paper. D.H. provided advice and revised the manuscript.

Funding: This research was funded by the National Natural Science Foundation of China under Grant No. 41671339, and the National Key Research and Development Program of China under Grant No. 2017 YFB0504102.

Acknowledgments: This work was jointly supported by the Chinese Natural Science Foundation Project (No. 41671339) and National Key Research and Development Program of China (No. 2017YFB0504102). We greatly appreciate to anonymous reviewers and editors for their professional comments and suggestions.

Conflicts of Interest: The authors declare no conflict of interest.

\section{References}

1. Wells, C.; Ketcheson, S.; Price, J. Hydrology of a wetland-dominated headwater basin in the Boreal Plain, Alberta, Canada. J. Hydrol. 2017, 547, 168-183. [CrossRef]

2. Carol, E.; Kruse, E.; Mancuso, M.; Melo, M. Local and Regional Water Flow Quantification in Groundwater-dependent Wetlands. Water Resour. Manag. 2013, 27, 807-817. [CrossRef]

3. Gharun, M.; Vervoort, R.W.; Turnbull, T.L.; Adams, M.A. A test of how coupling of vegetation to the atmosphere and climate spatial variation affects water yield modelling in mountainous catchments. J. Hydrol. 2014, 514, 202-213. [CrossRef]

4. Suzuki, T.; Ohta, T.; Hiyama, T.; Izumi, Y.; Mwandemele, O.; Iijima, M. Effects of the introduction of rice on evapotranspiration in seasonal wetlands. Hydrol. Process. 2014, 28, 4780-4794.

5. Gong, T.; Lei, H.; Yang, D.; Jiao, Y.; Yang, H. Monitoring the variations of evapotranspiration due to land use/cover change in a semiarid shrubland. Hydrol. Earth Syst. Sci. 2017, 21, 863-877. [CrossRef]

6. Tao, B.O.; Tian, H.; Chen, G.; Ren, W.; Lu, C.; Alley, K.; Xu, X.; Liu, M.; Pan, S.; Virji, H. Terrestrial carbon balance in tropical Asia: Contribution from cropland expansion and land management. Glob. Planet. Chang. 2013, 100, 85-98. [CrossRef]

7. Spera, S.A.; Galford, G.L.; Coe, M.T.; Mustard, J.F. Land-Use Change Affects Water Recycling in Brazil's Last Agricultural Frontier. Glob. Chang. Biol. 2016, 22, 3405-3413. [CrossRef] [PubMed]

8. Li, G.; Zhang, F.; Jing, Y.; Liu, Y.; Sun, G. Response of evapotranspiration to changes in land use and land cover and climate in China during 2001-2013. Sci. Total Environ. 2017, 596-597, 256-265. [CrossRef] [PubMed]

9. Kousari, M.R.; Ahani, H.; Hakimelahi, H. An investigation of near surface wind speed trends in arid and semiarid regions of Iran. Theor. Appl. Climatol. 2013, 114, 153-168. [CrossRef] 
10. Drexler, J.Z.; Snyder, R.L.; Spano, D.; Tha Paw, U.K. A review of models and micrometeorological methods used to estimate wetland evapotranspiration. Hydrol. Process. 2010, 18, 2071-2101. [CrossRef]

11. Dinpashoh, Y.; Jhajharia, D.; Fakheri-Fard, A.; Singh, V.P.; Kahya, E. Trends in reference crop evapotranspiration over Iran. J. Hydrol. 2011, 399, 422-433. [CrossRef]

12. Glenn, E.P.; Mexicano, L.; Garcia-Hernandez, J.; Nagler, P.; Gomez-Sapiens, M.; Tang, D.; Lomeli, M.; Ramirez-Hernandez, J.; Zamora-Arroyo, F. Evapotranspiration and water balance of an anthropogenic coastal desert wetland: Responses to fire, inflows and salinities. Ecol. Eng. 2013, 59, 176-184. [CrossRef]

13. Richardson, C.J.; Mccarthy, E.J. Effect of land development and forest management on hydrologic response in southeastern coastal wetlands: A review. Wetlands 1994, 14, 56-71. [CrossRef]

14. Li, Z.; Liu, W.Z.; Zhang, X.C.; Zheng, F.L. Impacts of land use change and climate variability on hydrology in an agricultural catchment on the Loess Plateau of China. J. Hydrol. 2009, 377, 35-42. [CrossRef]

15. Zhao, A.; Zhu, X.; Liu, X.; Pan, Y.; Zuo, D. Impacts of land use change and climate variability on green and blue water resources in the Weihe River Basin of northwest China. Catena 2016, 137, 318-327. [CrossRef]

16. Kim, J.; Choi, J.; Choi, C.; Park, S. Impacts of changes in climate and land use/land cover under IPCC RCP scenarios on streamflow in the Hoeya River Basin, Korea. Sci. Total Environ. 2013, 452-453, 181-195. [CrossRef]

17. Yin, J.; Ou, Z.; Fu, Q.; Liu, D.; Xing, Z. Review of Current Methodologies for Regional Evapotranspiration Estimation: Inversion and Data Assimilation. Sci. Geogr. Sin. 2018, 38, 448-456.

18. Kool, D.; Agam, N.; Lazarovitch, N.; Heitman, J.; Sauer, T.; Ben-Gal, A. A review of approaches for evapotranspiration partitioning. Agric. For. Meteorol. 2014, 184, 56-70. [CrossRef]

19. Mohamed, Y.A.; Bastiaanssen, W.G.; Savenije, H.H.; Van den Hurk, B.J.; Finlayson, C.M. Wetland versus open water evaporation: An analysis and literature review. Phys. Chem. Earth 2012, 47-48, 114-121. [CrossRef]

20. Awada, H.; Ciraolo, G.; Maltese, A.; Provenzano, A.; Hidalgo, G.; Còrcoles, M.; Ignacio, J. Assessing the performance of a large-scale irrigation system by estimations of actual evapotranspiration obtained by Landsat satellite images resampled with cubic convolution. Int. J. Appl. Earth Obs. Geoinf. 2019, 75, 96-105. [CrossRef]

21. Ortega-Farias, S.; Poblete-Echeverría, C.; Brisson, N. Parameterization of a two-layer model for estimating vineyard evapotranspiration using meteorological measurements. Agric. For. Meteorol. 2010, 150, 276-286. [CrossRef]

22. Tang, R.; Li, Z.; Chen, K.; Jia, Y.; Li, C.; Sun, X. Spatial-scale effect on the SEBAL model for evapotranspiration estimation using remote sensing data. Agric. For. Meteorol. 2013, 174-175, 28-42. [CrossRef]

23. Awan, U.K.; Ismaeel, A. A new technique to map groundwater recharge in irrigated areas using a SWAT model under changing climate. J. Hydrol. 2014, 519, 1368-1382. [CrossRef]

24. Carrascobenavides, M.; Ortegafarías, S.; Lagos, L.; Kleissl, J.; Morales-Salinas, L.; Kilic, A. Parameterization of the Satellite-Based Model (METRIC) for the Estimation of Instantaneous Surface Energy Balance Components over a Drip-Irrigated Vineyard. Remote Sens. 2014, 6, 11342-11371. [CrossRef]

25. Wang, X.G.; Wen, W.; Huang, D.; Yong, B.; Chen, X. Modifying SEBAL Model Based on the Trapezoidal Relationship between Land Surface Temperature and Vegetation Index for Actual Evapotranspiration Estimation. Remote Sens. 2014, 6, 5909-5937. [CrossRef]

26. Mkhwanazi, M.; Chávez, J.; Andales, A. SEBAL-A: A Remote Sensing ET Algorithm that Accounts for Advection with Limited Data. Part I: Development and Validation. Remote Sens. 2015, 7, 15046-15067. [CrossRef]

27. Brix, H.; Ye, S.; Laws, E.; Sun, D.; Li, G.; Ding, X.; Yuan, H.; Zhao, G.; Wang, J.; Pei, S. Large-scale management of common reed, Phragmites australis, for paper production: A case study from the Liaohe Delta, China. Ecol. Eng. 2014, 73, 760-769. [CrossRef]

28. Du, J.; Song, K. Validation of global evapotranspiration product (MOD16) using flux tower data from Panjin coastal wetland, Northeast China. Chin. Geogr. Sci. 2018, 28, 420-429. [CrossRef]

29. Liu, T.; Liu, X.; Du, J.; Song, K. Pattern and Change of Coastal Wetlands in the Liaohe River Delta for 5 Periods. Wetl. Sci. 2017, 15, 622-628.

30. Zhuang, L.; Wang, S. Spatial interpolation methods of daily weather data in Northeast China. J. Appl. Meteorol. Sci. 2003, 24, 605-615.

31. Bastiaanssen, W.; Mobin-ud-Din, A.; Chemin, Y. Satellite surveillance of evaporative depletion across the Indus Basin. Water Resour. Res. 2002, 38, 1273. [CrossRef] 
32. Zhan, C.; Yin, J.; Wang, H.; Chen, S. The regional evapotranspiration estimation using a two-layer model based on quantitative remote sensing in Shahe River Basin. J. Nat. Resour. 2013, 28, 161-170.

33. Zeng, L.; Song, K.; Zhang, B.; Du, J. Applying Landsat Data and SEBAL Model to Inverse Regional Evapotranspiration and Its Parameters Estimation. Remote Sens. Technol. Appl. 2008, 23, 255-263.

34. Liaqat, U.; Choi, M.; Awan, U. Spatio-temporal distribution of actual evapotranspiration in the Indus Basin Irrigation System. Hydrol. Process. 2015, 29, 2613-2627. [CrossRef]

35. Jia, L.; Xi, G.; Liu, S.; Huang, C.; Yan, Y.; Liu, G. Regional estimation of daily to annual regional evapotranspiration with MODIS data in the Yellow River Delta wetland. Hydrol. Earth Syst. Sci. 2009, 13, 1775-1787. [CrossRef]

36. Jassas, H.; Kanoua, W.; Merkel, B. Actual evapotranspiration in the Al-Khazir Gomal Basin (Northern Iraq) using the Surface Energy Balance Algorithm for Land (SEBAL) and water balance. Geosciences 2015, 5, 141-159. [CrossRef]

37. Guo, S.; Cheng, Z. Estimation of catchment evapotranspiration by climatic approach. Hydrology 1994, 5, $16-22$.

38. Ren, Z.; Li, M.; Zhang, W. Conversion coefficient of small evaporation pan into E-601B pan in China. J. Appl. Meteorol. Sci. 2002, 13, 508-512.

39. Eslamian, S.; Khordadi, M.J.; Abedi-Koupai, J. Effects of variations in climatic parameters on evapotranspiration in the arid and semi-arid regions. Glob. Planet. Chang. 2011, 78, 188-194. [CrossRef]

40. Nam, W.H.; Hong, E.M.; Choi, J.Y. Has climate change already affected the spatial distribution and temporal trends of reference evapotranspiration in South Korea? Agric. Water Manag. 2015, 150, 129-138. [CrossRef]

41. Zeng, L.; Song, K.; Zhang, B.; Wang, Z.; Du, J. Analysis of spatiotemporal variations in evapotranspiration and its influencing factors over the Songnen Plain in the growing season during the period 2000-2008. Resour. Sci. 2010, 32, 2305-2315.

42. Han, S.; Tian, F.; Hu, H. Positive or negative correlation between actual and potential evaporation? Evaluating using a nonlinear complementary relationship model. Water Resour. Res. 2014, 50, 1322-1336. [CrossRef]

43. Feng, C.; Zhang, Y.; Zhao, S.; Zhao, X.; Mi, Z. Correlation analysis between the evapotranspiration quantity and climatic factors of artificial grassland in Three River Sources areas. Agric. Sci. Technol. 2008, 9, 13-18.

44. Xu, Y.; Zhao, Q.; Ba, Y.; Bai, S.; Sun, D. Spatio-temporal variations of land surface evapotranspiration of Bosten Lake basin based on MODIS data. Sci. Geogr. Sin. 2012, 32, 1353-1357.

45. Shan, N.; Shi, Z.; Yang, X.; Gao, J.; Cai, D. Spatiotemporal trends of reference evapotranspiration and its driving factors in the Beijing-Tianjin Sand source control project region, China. Agric. For. Meteorol. 2015, 200, 322-333. [CrossRef]

46. Xu, L.; Shi, Z.; Wang, Y.; Zhang, S.; Chu, X.; Yu, P.; Xiong, W.; Zuo, H.; Wang, Y. Spatiotemporal variation and driving forces of reference evapotranspiration in Jing river basin, northeast China. Hydrol. Process. 2015, 29, 4846-4862. [CrossRef]

47. Han, J.; Wang, J.; Zhao, Y.; Wang, Q.; Zhang, B.; Li, H.; Zhai, J. Spatio-temporal variation of potential evapotranspiration and climatic drivers in the Jing-Jin-Ji region, North China. Agric. For. Meteorol. 2018, 256-257, 75-83. [CrossRef]

48. Sun, G.; Caldwell, P.; Noormets, A.; Mcnulty, S.G.; Cohen, E.; Moore, M.J.; Domec, J.C.; Treasure, E.; $\mathrm{Mu}, \mathrm{Q}$; Xiao, J. Upscaling key ecosystem functions across the conterminous United States by a water-centric ecosystem model. J. Geophys. Res. Biogeosci. 2011, 116, G00J05. [CrossRef]

49. Xu, F.; Bao, H.; Li, H.; Kwan, M.P.; Huang, X. Land use policy and spatiotemporal changes in the water area of an arid region. Land Use Policy 2016, 54, 366-377. [CrossRef]

50. Bronstert, A.; Niehoff, D.; Bürger, G. Effects of climate and land-use change on storm runoff generation: Present knowledge and modelling capabilities. Hydrol. Process. 2002, 16, 509-529. [CrossRef]

51. Olchev, A.; Ibrom, A.; Priess, J.; Erasmi, S.; Leemhuis, C.; Twele, A.; Radler, K.; Kreilein, H.; Panferov, O.; Gravenhorst, G. Effects of land-use changes on evapotranspiration of tropical rain forest margin area in Central Sulawesi (Indonesia): Modelling study with a regional SVAT model. Ecol. Model. 2008, 212, 131-137. [CrossRef]

52. Dias, L.; Macedo, M.; Costa, M.; Coe, M.; Neill, C. Effects of land cover change on evapotranspiration and streamflow of small catchments in the upper Xingu river basin, central Brazil. J. Hydrol. Reg. Stud. 2015, 4 Pt $B, 108-122$. [CrossRef] 
53. Douglas, E.M.; Jacobs, J.M.; Sumner, D.M.; Ray, R.L. A comparison of models for estimating potential evapotranspiration for Florida land cover types. J. Hydrol. 2009, 373, 366-376. [CrossRef]

54. Li, B.; Chen, Y.; Li, W.; Cao, Z. Remote Sensing and the SEBAL model for estimating evapotranspiration in the Tarim River. Acta Geogr. Sin. 2011, 66, 1230-1238.

55. Sánchez-Carrillo, S.; Angeler, D.G.; Sánchez-Andrés, R.; Alvarez-Cobelas, M.; Garatuza-Payána, J. Evapotranspiration in semi-arid wetlands: Relationships between inundation and the macrophyte-cover: Open-water ratio. Adv. Water Resour. 2004, 27, 643-655. [CrossRef]

(C) 2019 by the authors. Licensee MDPI, Basel, Switzerland. This article is an open access article distributed under the terms and conditions of the Creative Commons Attribution (CC BY) license (http://creativecommons.org/licenses/by/4.0/). 